\title{
sciendo
}

\author{
WIES ŁAWA JANISZEWSKA ${ }^{1}$, STANIS $Ł A W ~ M A N U L I K^{2}$, KRZYSZTOF CHMIELOWIEC ${ }^{3}$, \\ JOLANTA CHMIELOWIEC3, AGNIESZKA BOROŃ ${ }^{4}$
}

\section{Assessment of nurses' knowledge of nosocomial infections transmitted through contact}

\begin{abstract}
Introduction. Due to frequent contact with sick people, the hands of healthcare professionals are the most popular way of transmitting pathogens from patient to patient and from hospital to patient. Hand hygiene is crucial when it comes to reducing HCAI (healthcare-associated infections).

Aim. The aim is to analyze the professional knowledge of nurses about nosocomial infections transmitted through contact. Its main assumption is the evaluation of this knowledge in the context of preventing the spread of nosocomial infections.

Material and method. A proprietary questionnaire consisting of questions was used to assess the knowledge of medical personnel. The survey contains 25 questions based on the principle of "true/false". The reliability of the scale was measured and assessed with the Cronbach's alpha test at the level of $68.4 \%$.

Results. Factors adversely affecting the general level of knowledge in the field of hand hygiene turned out to be older age $(p=0.012)$, longer work experience $(p=0.023)$ and the lack of higher education $(p=0.048)$.
\end{abstract}

Keywords: hospital infections, knowledge, healthcare-associated infections.

DOI: $10.2478 /$ pjph-2020-0007

\section{INTRODUCTION}

The Act of December 5, 2008 on preventing and combating infections and infectious diseases in humans and nosocomial infection recognizes an infection that occurred in strict connection with the provision of medical services. The condition must be fulfilled that the disease at the time of its granting was not in the hatching period or occurred after the end of providing health services, but not later than the longest incubation period [1]. This means that a nosocomial infection appears during hospitalization, or the infection may appear after the end of treatment and the patient's discharge from the hospital. Such a general definition is only an introduction to a comprehensive study, because when diagnosing and monitoring infections, it is very important to adopt not only uniform concepts, but above all, acceptable criteria for diagnosing infections and their clinical forms [2,3].It is estimated that in Poland, nosocomial infections will occur in $5 \%$ to $10 \%$ of all patients, in addition, the more complicated the procedure is, the longer the hospital stay is, and the risk of nosocomial infection increases with the length of hospitalization. The size of the hospital is not insignificant in this matter - a larger hospital means more microbes circulating there [2,3]. Each hospital infection generates treatment costs, which per year for an average hospital (approx. 250 beds) can oscillate between 200 and 600 thousand zlotys. It is easy to imagine how much the elimination of this type of expense would have a healing effect on the economic situation of the Polish hospitals [1].

The NIK (Supreme Chamber of Control) reports that even 1 in 10 people treated in hospital may become ill due to an infection acquired in a hospital. Assuming that this calculation is true - it gives about 800 thousand people [4]. For obvious reasons, nosocomial infections are particularly vulnerable to people with decreased immunity: children, the elderly, patients during or after chemotherapy, radiotherapy and burns [5]. The increase in the number of nosocomial infections carries with it not only the obvious consequences such as the deterioration of patients' health and an increased risk of disease in healthy people, but also significant financial consequences related to the costs of treating these people. These amounts are not without significance for the hospital's budget. Reducing this problem may bring many positive effects when it comes to improving the functioning of the Polish healthcare system, because hospital infections prolong the recovery of patients and may also be the cause of death. This is a cumbersome and costly handicap, but it can be avoided or significantly minimized by maintaining the principles of antiseptics. Despite the efforts of medical staff, this goal is not always achieved. Therefore, the hospital becomes a place where drug-resistant microorganisms spread and infections occur [6].

For the development of nosocomial infection, three interconnected elements are necessary [7]. One of them is the source.

\footnotetext{
${ }^{1}$ A graduate of M.Sc. nursing, Faculty of Health Sciences, Medical University of Wrocław, Poland

2 Department of Nervous System Diseases, Department of Clinical Nursing, Faculty of Health Sciences, Medical University of Wrocław, Poland

${ }^{3}$ Department of Hygiene and Epidemiology, Collegium Medicum, University of Zielona Góra, Poland

${ }^{4}$ Department of Clinical and Molecular Biochemistry, Pomeranian Medical University, Szczecin, Poland
} 
The etiological factor of the source of endogenous infection are microorganisms that are part of the patient's natural flora, while the exogenous infections are factors from the hospital environment [8]. It can be both an inanimate environment, e.g. medical equipment, tools, and a living environment, e.g. other sick, personnel. Another determinant is the patient's susceptibility to infections and their risk factors. The route of transmission is the last element of an interaction that leads to infection. There are several ways for microbes to spread in hospital settings. They can be divided into air-dust, air-droplet and contact [3]. The etiological factors of nosocomial infections can be viruses, bacteria, fungi and prions.

The cause of microbial translocation are the aforementioned transmission routes, including the one for which medical personnel is responsible. Compliance with the rules of hand disinfection among hospital employees is one of the most effective measures aimed at minimizing the incidence of nosocomial infections [9]. It is an easy operation, but only strict observance of it may interrupt the path of transmission of pathogenic microorganisms. Failure to observe the rules of hand hygiene during contact with a patient, while performing nursing and therapeutic activities, is considered to be of great importance in the development of infections [10]. Only understanding the possible consequences of nosocomial infections, knowledge of pathogens and knowledge of the transmission pathways of pathogenic microorganisms that are sources of nosocomial infections can prompt hospital staff to take measures to reduce the spread of nosocomial infections.

Due to frequent contact with patients, the hands of healthcare professionals are the most popular way of transmitting pathogens from patient to patient and from hospital environment to patient [12]. Different nursing specialties differ in terms of exposure to body fluids and the type of contact with patients, but the differences are not significant. Hand hygiene is of key importance when it comes to reducing HCAI (healthcare-associated infections) [12].

\section{AIM}

The aim of the study was to assess the knowledge of medical personnel about nosocomial infections transmitted through contact with the use of questionnaires. The collected information is to raise awareness of the importance of preventing nosocomial infections.

\section{MATERIAL AND METHODS}

\section{Survey questionnaire}

The research was carried out using a self-authored questionnaire consisting of 24 items providing answers in the form of "YES" or "NO", one question consisting in selecting several correct answers and one question assuming the selection of one correct answer. In total, the questionnaire consisted of 26 questions and was based on the principles developed by the WHO on hand hygiene. The reliability of the method was checked using the Cronbach's alpha coefficient, which was $68.4 \%$

\section{Study group}

The number of 108 respondents, nurses working in Wrocław in 2019 , took part in the study. The study group included 6
(5.6\%) people aged 20-30, $28(25.9 \%)$ aged 31-40, $34(31.5 \%)$ aged $41-50,35(32.4 \%)$ aged 51-60 years of age and $5(4.6 \%)$ aged 61 and over. In order to ensure adequate statistical power, further analysis included three groups: respondents aged up to $40(n=34)$, respondents aged $41-50(n=34)$ and respondents aged 51 and above $(n=40)$.

The study group included $37(34.3 \%)$ graduates of medical secondary school, 5 (4.6\%) of medical studies, 49 (45.4\%) with a bachelor's degree and $17(15.7 \%)$ with a master's degree. In order to ensure the appropriate power of statistical calculations, two groups were included into the further analysis: respondents with secondary education (medical secondary school or medical college, $\mathrm{n}=42$ ) or higher education (bachelor's or master's degree, $\mathrm{n}=66$ ). The study group included 48 $(44.4 \%)$ people working in the surgical ward and $60(55.6 \%)$ working in the conservative ward. The study group included $11(10.2 \%)$ people caring for 6-15 patients, 36 (33.3\%) people caring for $16-25$ patients, 54 (50.0\%) people caring for $26-30$ patients and $7(6.5 \%)$ people caring for 31 or more patients. In order to ensure the appropriate power of statistical calculations, two groups were included into the further analysis: respondents caring for up to 25 patients $(n=47)$ and people caring for 26 and more patients $(n=61)$.

\section{Statistical methods}

The normality of the distribution of the measurable variable (respondents' level of knowledge) was determined using the Shapiro-Wilk test. The statistical characteristics of the variable are presented as arithmetic means (M), standard deviations (SD), medians, lower and upper quartile values (Q25 and Q75), minimum (Min) and maximum (Max) values. Statistical characteristics of discrete variables (metric characteristics of study participants, frequency of correct answers to survey questions) were presented in the form of numerical and percentage distributions. As the distribution of the measurable variable deviated from the normal, the Mann-Whitney U test (in the case of comparing two groups) and the Kruskal-Wallis test with Dunn's post-hoc test (in the case of comparing more than two groups) were used for intergroup comparisons of its statistical characteristics. The $\mathrm{p}$ value $<0.05$ was adopted as the threshold of statistical significance for all tests.

\section{RESULTS}

Statistical characteristics of the general level of knowledge of the study participants, expressed as the sum of correct answers to the survey questions, are presented in Table 1, and the scoring distribution - in Table 2. The mean number of points obtained by the study participants was $26.9 \pm 2.5$ (median 27). One respondent achieved the lowest result in the whole group, 15 points. Four respondents scored the maximum number of 31 points. The lowest $25 \%$ of scores ranged from 15 to 25 points, and the top $25 \%$ ranged from 29 to 31 points.

TABLE 1. Statistical characteristics of the general level of knowledge of the study participants (the sum of correct answers to the survey questions).

\begin{tabular}{ccccccc}
\hline \hline M & SD & Median & Min. & Max. & Q25 & Q75 \\
\hline 26.9 & 2.5 & 27 & 15 & 31 & 25 & 29
\end{tabular}


TABLE 2. Distribution of the general level of knowledge of the study participants (the sum of correct answers to the survey questions).

\begin{tabular}{|c|c|c|}
\hline Total points & $\mathbf{n}$ & $\%$ \\
\hline 15 & 1 & 0.9 \\
\hline 18 & 1 & 0.9 \\
\hline 22 & 1 & 0.9 \\
\hline 24 & 8 & 7.4 \\
\hline 25 & 17 & 15.7 \\
\hline 26 & 22 & 20.4 \\
\hline 27 & 13 & 12.0 \\
\hline 28 & 18 & 16.7 \\
\hline 29 & 7 & 6.5 \\
\hline 30 & 16 & 14.8 \\
\hline 31 & 4 & 3.7 \\
\hline
\end{tabular}

Age also had a statistically significant effect on the total level of knowledge of the respondents $(p=0.012)$. The posthoc analysis showed that the total level of knowledge of respondents aged 51 and above was significantly lower than that of respondents aged up to $40(\mathrm{p}=0.014$, Table 3$)$.

TABLE 3. Statistical characteristics of the general level of knowledge of the study participants (the sum of correct answers to the questionnaire questions) depending on the age of the study participants.

\begin{tabular}{lcccc}
\hline \hline \multicolumn{1}{c}{ Age } & Median & Min. & Max. & p \\
\cline { 1 - 4 } up to 40 years & 28 & 24 & 31 & \\
\cline { 1 - 4 } 41-50 years & 26 & 18 & 31 & 0.012 \\
\cline { 1 - 4 } 51+ years & 26 & 15 & 30 & \\
\hline
\end{tabular}

The level of education had a statistically significant effect on the total level of knowledge of the female respondents $(p=0.048)$. It was shown that the total level of knowledge of the respondents with higher education was slightly, but statistically significantly higher than in the case of respondents with secondary education (Table 4).

TABLE 4. Statistical characteristics of the general level of knowledge of the study participants (the sum of correct answers to the survey questions) depending on the education level of the study participants.

\begin{tabular}{lcccc}
\hline \multicolumn{1}{c}{ Education } & Median & Min. & Max. & p \\
\cline { 1 - 4 } secondary & 26 & 15 & 31 & \multirow{2}{*}{0.048} \\
\cline { 1 - 4 } higher & 27 & 18 & 31 & \\
\hline
\end{tabular}

The work experience also had a statistically significant effect on the total level of knowledge of the respondents $(p=0.023)$. The post-hoc analysis showed that the total level of knowledge of the respondents with work experience of 31 years and above was significantly lower than in the case of respondents with work experience up to 20 years $(\mathrm{p}=0.036$, Table 5).

TABLE 5. Statistical characteristics of the general level of knowledge of the survey participants (the sum of correct answers to the survey questions) depending on the length of service of the survey participants.

\begin{tabular}{lcccc}
\hline \hline \multicolumn{1}{c}{ Seniority } & Median & Min. & Max. & p \\
\cline { 1 - 4 } up to 20 years & 28 & 24 & 31 & \\
\cline { 1 - 4 } 21-30 years & 26.5 & 18 & 31 & \multirow{2}{*}{0.023} \\
\cline { 1 - 4 } 31+ years & 26 & 15 & 30 & \\
\hline
\end{tabular}

The type of hospital ward employed did not have a statistically significant impact on the total level of knowledge of the respondents $(\mathrm{p}=0.474$, Table 6$)$.

TABLE 6. Statistical characteristics of the general level of knowledge of the study participants (the sum of correct answers to the survey questions) depending on the nature of the hospital ward employing the study participants.

\begin{tabular}{ccccc}
\hline \hline Hospital ward & Median & Min. & Maź. & p \\
\cline { 1 - 4 } surgery department & 27 & 24 & 31 & \\
\cline { 1 - 4 } conservative ward & 27 & 15 & 31 &
\end{tabular}

Despite the differences, the number of patients did not have a statistically significant effect on the total level of knowledge of the respondents $(\mathrm{p}=0.394$, Table 7$)$.

TABLE 7. Statistical characteristics of the general level of knowledge of the study participants (the sum of correct answers to the questionnaire questions) depending on the average number of patients under the care of the study participants.

\begin{tabular}{lcccc}
\hline \hline Number of patients & Median & Min. & Max. & p \\
\cline { 1 - 4 } up to 25 & 27 & 18 & 31 & \multirow{2}{*}{0.394} \\
\cline { 1 - 4 } 26 and more & 27 & 15 & 31 & \\
\hline
\end{tabular}

\section{DISCUSSION}

According to the latest available data, there was an increase in the number of nosocomial infections with a simultaneous decrease in the number of hospitalized patients in Poland. In 2016, there was a threefold increase in the number of patients infected with drug-resistant strains of Klebsiella Pneumoniae $\operatorname{NDM}(+)$ [13], this microorganism is a very serious epidemiological problem in health care facilities. Klebsiella Pneumoniae NDM (+) is resistant to the vast majority of antibiotics, and it can persist in the digestive system of the host for up to several years, spreading during this time [14].

Hand-transmitted infections account for from 20 to $40 \%$ of all nosocomial infections [15]. Such infection can be a threat to both patients and employees of medical facilities. The respondents with higher education significantly more often answered correctly to almost half of the questions in the survey than the staff with secondary education. On the basis of these studies [16], it can be concluded that the knowledge of nurses about nosocomial infections transmitted by contact depends on their education in such a way that the higher it is, the better the person can be proud of.

Other studies illustrate the importance of knowledge about contact-transmitted nosocomial infections. Their results showed that the knowledge of nurses about infections varied and was more dependent on the type of ward. The biggest number of correct answers were provided by the staff employed in surgical wards. Most of the respondents answered the question regarding the definition of nosocomial infection correctly. Comparable results were obtained in the studies of this work [11].

The research conducted by Kosonóg and Gotib was aimed at assessing the knowledge of compliance with hygiene procedures. As much as $99 \%$ of respondents believed that hand hygiene is the most important method of preventing infections. When asked about the most important vector of infection transmission, $69 \%$ of the respondents indicated that these are 
hands. To the next question whether the use of gloves releases hand disinfection, $98 \%$ of respondents answered that they did not. The results of the cited work are largely consistent with the results of my own research. The authors of the study also found the development and implementation of training for nurses on methods of preventing nosocomial infections very important [17].

In the own study, when assessing the responses to the survey questions globally, it should be stated that the level of knowledge among the staff of the treatment ward and those with higher education is greater, it should be emphasized that the differences between wards in the sum of correct answers to individual questions are small. In other words, these are disproportions so small that their cause may also be a measurement error or random fluctuations in the psychophysical state of the surveyed staff.

To sum up, the general knowledge of the surveyed medical personnel about nosocomial infections transmitted by contact should be considered good, as the vast majority of respondents answered the vast majority of questions correctly. Additionally, for the most part, there was almost unanimity as to the answers provided. This may prove that the knowledge of nurses is unified and standardized. While research has shown that healthcare professionals have good knowledge of nosocomial contact-borne infections, there are also areas for further training. Several "controversial" questions were identified, to which incorrect answers were given more often than others. It would be advantageous to reexamine them and perhaps pay attention to them when designing retraining and revision tools for medical and support personnel. The more answers to the question about participation in the last year of training on nosocomial infections compared to the preceding question - with the willingness to participate in this type of training, clearly indicates that the staff intends to train and improve their knowledge.

An unequivocal and certain conclusion from both the study itself and the analyzed other works as well as the theoretical part of the literature (especially publications on the scale of nosocomial infections in Poland) is the fact that regular testing of knowledge is something necessary and helpful in diagnosing possible gaps in the knowledge of staff. This should be taken into account especially in the field of nursing, where any loss in the competences of a single employee may result in an increase in the incidence of hospital infections transmitted through contact.

\section{CONCLUSIONS}

The level of knowledge of the vast majority of respondents in the field of hand hygiene should be considered high or moderately high. Factors adversely affecting the general level of knowledge in the field of hand hygiene turned out to be older age, longer work experience and the lack of higher education. These dependencies suggest that the older respondents/those who work longer and do not have higher education may show a lack of knowledge in the field of hand hygiene and should be covered by supplementary training on this topic.

\section{REFERENCES}

1. Mączyńska A, Karwacka M, Świerczyńska B. Wpływ higieny rąk na redukcję kosztów związanych z występowaniem zakażeń szpitalnych. Twoje zdrowie. 2013:48-51.

2. Bulanda M, Wójkowska-Mach J. Zakażenia szpitalne w jednostkach opieki zdrowotnej. Warszawa: Warszawa; 2016. p.1-19.

3. Czajka E, Pancer K, Kochman M, et al Charakterystyka bakterii wyizolowanych $\mathrm{z}$ powierzchni ciała karaczanów prusaków występujących w środowisku szpitalnym. Przegl Epidemiol. 2003;74(2):655-7.

4. Najwyższa Izba Kontroli. Zakażenia w szpitalach poważnym problemem. [https://www.nik.gov.pl/aktualnosci/zakazenia-w-szpitalach-powaznymproblemem.html]

5. Zakażenie szpitalne leczenie i objawy. Definicje według WHO 2010. [http://leczenie - objawy. pl/zakażenia. htm, 2012.]

6. Caetano JA, Lima MA, Miranda MD, et al. Identification of bacterial contamination in liquid soap for hospital use. Rev Esc USP. 2011;45(1):153-6.

7. Lik K. Zakażenia szpitalne w wybranych Oddziałach. Warszawa: ABC; 2013. p. 197-8.

8. Martirosian G, Hryniewicz W, Ozorowski T. Zakażenia Clostridioides (Clostridium) difficile: epidemiologia, diagnostyka, terapia, profilaktyka. Warszawa: Narodowy Instytut Leków; 2018. p.15-6.

9. Wojciechowski A. Status wdrażania wieloaspektowej strategii przestrzegania higieny rąk Światowej Organizacji Zdrowia w Stanach Zjednoczonych. Zakażenia. 2016;5:9-18.

10. Fleischer M. Higiena szpitalna. Zakażenia szpitalne. Podręcznik dla zespołów kontroli zakażeń. Warszawa: PZWL; 2014. p.162-3.

11. Chwedoruk M, Gotlib J. Ocena wiedzy pielęgniarek z oddziałów zabiegowych na temat zakażeń szpitalnych przenoszonych drogą kontaktowa. Med Ogólna Nauki Zdr. 2014;20(2):192-8.

12. Różkiewicz D. Ręce personelu jako potencjalne źródło zakażeń szpitalnych. Zakażenia. 2011;12:6-12.

13. Mączyńska A. Enterobacteriaceae produkujące karbapenemazy (CPE) nowe wyzwanie dla zespołów ds. kontroli zakażeń szpitalnych. Zakażenia. 2016;16:69-70.

14. Schwaber M, Lev B, Israeli A, et al. Conttainment of country - wide outbreak of carbapenemresistant Klebsiella pneumoniae in Israeli hospitals via a Nationally Implemented. Clin Infect Dis. 2011;52(7):848-55.

15. Przewodnik dotyczący higieny rąk opracowany przez WHO. World Health Organization, Hand Hygiene: Why, How \& When? Your 5 moments for hand hygiene: 1-7. [https://www.who.int/gpsc/5may/Hand_Hygiene Why_How_and_When_Brochure.pdf?fbclid=IwAR3S11DOj6-ONK8H3NeW̄JlUcThk0-'JJfQfSfhMAdvE6GLDwCy8urO2icScg]

16. Stewardson AJ, Sax H, Gayet-Ageron A, et al. Enhanced performance feedback and patient participation to improve hand hygiene compliance of health-care workers in the setting of established multimodal promotion: a single-centre, cluster randomised controlled trial. Lancet Infect Dis. 2016;16(12):1345-55.

17. Kosonóg K, Gotib J. Ocena wiedzy pielęgniarek na temat aseptyki $\mathrm{i}$ antyseptyki w wybranych procedurach medycznych. Probl Pielęg. 2010;18(1):30-40

\section{Corresponding author}

Dr Krzysztof Chmielowiec

Department of Hygiene and Epidemiology Faculty of Medicine and Health

Sciences, Collegium Medicum, University of Zielona Góra

28 Zyty St., 65-046 Zielona Góra

E-mail: k.chmielowiec@wln.uz.zgora.p 